\title{
Evaluation of antinociceptive activity of hydromethanol extract of Cyperus rotundus in mice
}

\author{
Mohammad Zafar Imam* and Chandra Datta Sumi
}

\begin{abstract}
Background: Cyperus rotundus Linn. (Cyperaceae) is used to treat inflammation, pain, fever, wounds, boils and blisters in folk medicine. This study evaluated the antinociceptive effect of the hydromethanol extract of whole plant of C. rotundus (HMCR).

Methods: The antinociceptive activity of HMCR was investigated in thermal-induced (hot plate and tail immersion) and chemical-induced (formalin) nociception models in mice at three different doses (50, 100 and $200 \mathrm{mg} / \mathrm{kg} ;$ p.o.). Morphine sulphate (5 mg/kg, i.p.) and diclofenac sodium (10 mg/kg, i.p.) were used as reference analgesic agents.

Results: In the hot-plate and tail-immersion tests HMCR significantly increased the latency period to the thermal stimuli at all the tested doses $(50,100$ and $200 \mathrm{mg} / \mathrm{kg})(p<0.05)$. The significant increase in latency is clear from the observations at 60 and 90 min. In formalin-induced paw licking test oral administration of HMCR at 100 and $200 \mathrm{mg} / \mathrm{kg}$ doses decreased the licking of paw in early phase. All the tested doses $(50,100$ and $200 \mathrm{mg} / \mathrm{kg}$ ) significantly decreased the licking of paw in late phase of the test $(p<0.001)$. The dose $200 \mathrm{mg} / \mathrm{kg}$ was most effective showing maximum percentage of inhibition of licking in both early (61.60\%) and late phase (87.41\%).

Conclusion: These results indicate the antinociceptive effect of $C$. rotundus and suggest that this effect is mediated by both peripheral and central mechanisms. These results support the traditional use of this plant in different painful conditions.
\end{abstract}

Keywords: Analgesic, Cyperaceae, Cyperus rotundus, Medicinal plant, Pain

\section{Background}

The genus Cyperus includes common weeds found mainly in upland, paddy fields as well as marshy places in tropical, subtropical and temperate regions. Cyperus rotundus Linn., commonly known as nutgrass, is a perennial, herbaceous sedge with scaly creeping rhizomes and bulbous at the base. It is locally known as "Mutha". The plant is a widely used traditional medicinal herb in India, China, Japan, Korea, Combodia, Nigeria, and Bangladesh. Mainly the rhizomatous tubers are used in stomach and bowel disorders, inflammatory diseases [1,2], as an analgesic, a sedative drug [1] etc. Besides many other uses, this plant is used in different painful conditions such as inflammation, pain, fever, wounds, boils and blisters [3]. Different

\footnotetext{
* Correspondence: zafarimam@gmail.com

Department of Pharmacy, Stamford University Bangladesh, 51 Siddeswari Road, Dhaka 1217, Bangladesh
}

chemical compounds such as alkaloids, flavonoids, tannins, starch, glycosides, furochromones, monoterpenes, sesquiterpenes, sitosterol, essential oil, fatty oil containing a neutral waxy substance, glycerol, linolenic, myristic and stearic acids and many other compounds have been isolated from the plant $[3,4]$. Pharmacological properties such as anti-candida [5], anti-inflammatory [6], antidiabetic [7], antidiarrhoeal [8,9], cytoprotective [10], antimutagenic [11], antimicrobial, antioxidant [12], antibacterial, cytotoxic and apoptotic [13,14], analgesic [15], anticonvulsant [16], and wound healing [17] activities have been reported.

The use of C. rotundus in different painful conditions in folk medicine but lack of scientific study reporting its antinociceptive activity in both chemical- and heat-induced nociception models convinced us to design the present 
study to evaluate the antinociceptive effect of hydromethanol extract of the whole plant of C. rotundus.

\section{Methods}

\section{Plant materials and extract preparation}

The whole plant of $C$. rotundus Linn. was collected from Manikgonj district of Bangladesh in October, 2012. The collected plants were then identified by the experts of National Herbarium, Mirpur, Dhaka, Bangladesh (Accession No. 37861) where a voucher specimen has been deposited for further reference. The whole plant samples were washed, dried, grounded and $250 \mathrm{~g}$ of the dried powder was taken in a beaker. Then methanol and water (70:30) was added at the amount of $840 \mathrm{ml}$ and $360 \mathrm{ml}$ respectively and it was kept for three days with occasional stirring. Then it was filtered using a sterilized cotton filter and dried using rotary evaporator. After drying, $21.9 \mathrm{~g}$ (yield $8.76 \%$ ) of dried extract was obtained from $250 \mathrm{~g}$ of powder. This crude extract was used for the investigation.

\section{Chemicals}

Diclofenac sodium (Square Pharmaceuticals Ltd., Bangladesh), Morphine sulphate (Gonoshasthaya Pharmaceuticals Ltd., Bangladesh), 0.9\% Sodium chloride solution (Normal saline) (Orion Infusion Ltd., Bangladesh), Formalin (Merck, Germany) and other reagents were of analytical grade.

\section{Animals \\ Swiss Albino mice (20-25 g) were collected from the Ani- mal Resources Branch of the International Center for Diar- rhoeal Disease Research, Bangladesh (ICDDR,B). Animals were housed in cages and were maintained under stan- dard environmental conditions (Temperature: $24.0 \pm 1.0^{\circ} \mathrm{C}$; relative humidity: 55-65\%; $12 \mathrm{hrs}$ light/12 hrs dark cycle). Pellets of mice food prepared by ICDDR,B were given to the mice with fresh water ad libitum. All the experimental animals were treated following the Ethical Principles and Guidelines for Scientific Experiments on Animals (1995) formulated by The Swiss Academy of Medical Sciences and the Swiss Academy of Sciences. The study protocol was approved by the Ethics Committee of Stamford University Bangladesh.}

\section{Acute toxicity test}

Mice were divided into control and four test groups $(n=5)$. The test groups received HMCR orally at the doses of 1000, 1500, 2000, and $3000 \mathrm{mg} / \mathrm{kg}$ body weight. After gavage the animals were kept in separate cages and were allowed to food and water ad libitum. The animals were then observed for possible behavioral changes, allergic reactions (skin rash, itching) and mortality for the next $72 \mathrm{~h}[18]$.

\section{Hot plate test}

The hot-plate test was performed according to the method described by Eddy and Leimbach (1953) [19] with slight modification. The temperature of the metal surface of Eddy's hotplate was set at $52 \pm 2{ }^{\circ} \mathrm{C}$. The mice that showed fore paw licking, withdrawal of the paw(s) or jumping response within $15 \mathrm{~s}$ on hotplate were selected for this study $24 \mathrm{~h}$ prior to the experiment. Mice were fasted overnight with water given ad libitum. The mice were then treated with $0.9 \%$ sodium chloride solution as vehicle $(0.1 \mathrm{ml} /$ mice, p.o.), HMCR (50, 100, and $200 \mathrm{mg} / \mathrm{kg}$ ), and morphine as positive control (5 mg/kg, i.p.). HMCR was administered (50, 100 and $200 \mathrm{mg} / \mathrm{kg}$, p.o.) $30 \mathrm{~min}$ before the experiment while morphine sulphate was administered (5 $\mathrm{mg} / \mathrm{kg}$, i.p.) $15 \mathrm{~min}$ before the experiment. The response in the form of fore paw licking, withdrawal of the paw(s) or jumping was recorded at 30, 60, 90, and $120 \mathrm{~min}$ following treatment. A cut off period of $20 \mathrm{~s}$ was maintained to avoid paw tissue damage. The results of the hot plate test are expressed as a percentage of the maximal possible effect (\%MPE), which was calculated using following formula:

$$
\begin{aligned}
\% \mathrm{MPE}= & {[(\text { Postdrug latency }- \text { predrug latency })} \\
& /(\text { Cut off period }- \text { predrug latency })] \times 100 .
\end{aligned}
$$

\section{Tail immersion test}

This test is based on the observation that morphine like drugs selectively prolongs the reaction time of the typical tail-withdrawal reflex in mice [20,21]. HMCR was administered (50, 100 and $200 \mathrm{mg} / \mathrm{kg}$, p.o.) $30 \mathrm{~min}$ before the experiment and morphine sulphate was administered ( $5 \mathrm{mg} / \mathrm{kg}$, i.p.) $15 \mathrm{~min}$ before the experiment. 1 to $2 \mathrm{~cm}$ of the tail of mice was immersed in warm water kept constant at $52 \pm 1^{\circ} \mathrm{C}$. The reaction time was the time taken by the mice to deflect the tail. The latency period of the tail-withdrawal response was taken as the index of antinociception and was determined at 30,60, 90, and $120 \mathrm{~min}$ after the treatments. To determine the baseline, each animal was tested before administration of drug/extract. The \%MPE was calculated using the same formula used in hot plate test.

\section{Formalin-induced paw licking test}

Formalin-induced paw licking test was performed as describe by Santos and Calixto [22] and Santos et al. [23]. $20 \mu \mathrm{L}$ of $2.5 \%$ formalin solution ( $0.92 \%$ of formaldehyde), made up in saline water, was injected into the sub-plantar area of the right hind paw of mice. Animals were pretreated with different doses of HMCR (50, 100 and $200 \mathrm{mg} / \mathrm{kg}$, p.o.) $60 \mathrm{~min}$ before formalin injection. Control group received only the vehicle $(0.1 \mathrm{ml} / \mathrm{kg}$ saline water $)$. Mice treated with morphine (5 mg/kg, i.p.) $15 \mathrm{~min}$ before 
the formalin injection was categorized as positive control. Licking of the injected paw was counted from 0-5 min (first phase) and 15-30 min (second phase) after formalin injection, corresponding to the neurogenic and inflammatory pain responses, respectively. The initial response was initially attributed to a direct algogenic effect of formalin on the nociceptors whereas phase two was associated with the release of local endogenous mediators responsible for sensitization of primary and spinal sensory neurons and subsequent activation of the nociceptors [24].

\section{Statistical analysis}

The results are presented as Mean \pm SEM. The one-way ANOVA test with Dunnett's post hoc test was used to analyze the data using SPSS 11.5 software. $p<0.05-0.001$ were considered as statistically significant.

\section{Results and discussion}

\section{Acute toxicity}

Administration of HMCR at the doses 1000, 1500, 2000 and $3000 \mathrm{mg} / \mathrm{kg}$ did not cause any mortality, behavioral changes, or allergic reactions. So it can be said that $\mathrm{LD}_{50}$ of C. rotundus is more than $3000 \mathrm{mg} / \mathrm{kg}$ and therefore it showed low toxicity profile.

\section{Hot plate test}

Table 1 shows the antinociceptive effect of HMCR and standard drug (Morphine) assessed using the hot plate test. HMCR, at the doses of 100 and $200 \mathrm{mg} / \mathrm{kg}$, exhibited significant $(p<0.001)$ ability to prolong the latency of response to thermal-induced nociception throughout the whole experimental period. The effect was dose-dependent and HMCR showed stronger effect at 100 and $200 \mathrm{mg} / \mathrm{kg}$ doses. The extract showed significant \%MPE at 50, 100 and $200 \mathrm{mg} / \mathrm{kg}$ doses.

The hot-plate test is a specific test carried out to verify involvement of central mechanism with compounds/drugs showing antinociceptive activity [25]. In this work, HMCR showed a marked inhibition on thermal-induced hyperalgesia as it showed significant increase in latency $(\mathrm{p}<0.001)$ compared to control. Morphine (5 $\mathrm{mg} / \mathrm{kg}$ i.p.) was used as a standard drug which demonstrated a stronger analgesic effect than HMCR. The effect was evident from the elongation of the latency time till the $3^{\text {rd }}$ observation (90 min). The effect of compounds or plant extract in such mechanism by increasing the latency are suggested to act like centrally mediated drugs [26] by activating the periaqueductal gray matter (PAG) to release endogenous peptides (i.e., endorphin or enkephalin). These endogenous peptides descend the spinal cord and function as inhibitors of the pain impulse transmission at the synapse in the dorsal horn [27].

\section{Tail immersion test}

The tail-withdrawal reflex time of the mice to the hot water-induced pain was also significant after administration of HMCR (Table 2). The effect of HMCR at 100 and $200 \mathrm{mg} / \mathrm{kg}$ doses at 60 and $90 \mathrm{~min}$ was significant $(p<0.05)$ in comparison to control while at dose $50 \mathrm{mg} / \mathrm{kg}$ it did not show any significant increase in latency. The maximum effect of the extract was recorded at $60 \mathrm{~min}$. However, the increase in latency was less significant than that observed in the hot plate test. Morphine at $5 \mathrm{mg} / \mathrm{kg}$ showed highest \%MPE values while the extract also showed significant \%MPE at 100 and $200 \mathrm{mg} / \mathrm{kg}$ doses $(p<0.05)$ at different observation time.

Tail immersion model is considered as an acute pain model. The tail-withdrawal response of mice is predominantly considered to be selective for centrally acting analgesics, whereas the peripherally acting drugs are known to be inactive on such heat-induced pain response [28]. The significant increase $(p<0.05)$ in tail-withdrawal time by the extract suggests the involvement of central mechanisms in its antinociceptive effect. Both tail immersion and hot plate test measure the latency time of mice to thermal stimuli. Tail immersion monitors a spinal reflex involving $\mu_{2}$ - and $\delta$-opioid receptors, whereas the hot plate demonstrates supraspinal reflex mediated by $\mu_{1}$ - and $\mu_{2}$-opioid receptors [29]. Therefore, the results of the present study indicate that the central antinociceptive effect of $C$. rotundus may be prominent on $\mu$-opioid receptors.

Table 1 Antinociceptive effect of $C$. rotundus extract and morphine in hot plate test

\begin{tabular}{|c|c|c|c|c|c|c|}
\hline \multirow[t]{2}{*}{ Treatment } & \multirow{2}{*}{$\begin{array}{l}\text { Dose } \\
(\mathrm{mg} / \mathrm{kg})\end{array}$} & \multicolumn{5}{|c|}{ Response time (s) (\%MPE) } \\
\hline & & Pretreatment & $30 \mathrm{~min}$ & $60 \mathrm{~min}$ & $90 \mathrm{~min}$ & $120 \mathrm{~min}$ \\
\hline Vehicle & $0.1 \mathrm{ml} / \mathrm{mice}$ & $7.44 \pm 0.48$ & $7.89 \pm 0.62$ & $7.52 \pm 0.86$ & $7.91 \pm 0.90$ & $8.44 \pm 0.83$ \\
\hline Morphine sulphate & 5 & $8.70 \pm 0.72$ & $14.89 \pm 1.01 * *(54.72)$ & $18.17 \pm 0.66^{* *}(83.76)$ & $14.70 \pm 0.26^{* *}(53.04)$ & $12.99 \pm 0.93(37.94)$ \\
\hline HMCR & 50 & $8.22 \pm 0.91$ & $10.27 \pm 0.55(17.45)$ & $11.97 \pm 0.28 *(31.89)$ & $10.85 \pm 0.90(22.35)$ & $9.22 \pm 1.32(8.52)$ \\
\hline HMCR & 100 & $6.19 \pm 0.91$ & $10.11 \pm 0.72(28.38)$ & $13.03 \pm 1.18^{* *}(49.55)$ & $11.63 \pm 0.97 *(39.43)$ & $10.77 \pm 0.83(33.17)$ \\
\hline HMCR & 200 & $8.22 \pm 0.72$ & $12.21 \pm 0.62 *(33.89)$ & $13.93 \pm 0.63^{* *}(48.51)$ & $11.99 \pm 0.76 *(32.04)$ & $11.07 \pm 1.47(24.19)$ \\
\hline
\end{tabular}

Each value is presented as the mean \pm SEM $(n=5) ;{ }^{*} p<0.05$ compared with the control group (Dunnett's test). ${ }^{* *} p<0.001$ compared with the control group (Dunnett's test). 
Table 2 Antinociceptive effect of $C$. rotundus extract and morphine in tail immersion test

\begin{tabular}{|c|c|c|c|c|c|c|}
\hline \multirow[t]{2}{*}{ Treatment } & \multirow{2}{*}{$\begin{array}{l}\text { Dose } \\
(\mathrm{mg} / \mathrm{kg})\end{array}$} & \multicolumn{5}{|c|}{ Response time (s) (\%MPE) } \\
\hline & & Pretreatment & $30 \mathrm{~min}$ & $60 \mathrm{~min}$ & $90 \min$ & $120 \mathrm{~min}$ \\
\hline Vehicle & $0.1 \mathrm{ml} / \mathrm{mice}$ & $2.83 \pm 0.48$ & $2.62 \pm 0.37$ & $2.68 \pm 0.46$ & $2.66 \pm 0.43$ & $2.59 \pm 0.48$ \\
\hline Morphine sulphate & 5 & $2.66 \pm 0.56$ & $5.42 \pm 0.47 * *(37.62)$ & $6.21 \pm 0.41 * *(48.32)$ & $4.64 \pm 0.31 *(26.00)$ & $3.57 \pm 0.40(12.45)$ \\
\hline HMCR & 50 & $2.31 \pm 0.37$ & $3.25 \pm 0.47(12.22)$ & $3.98 \pm 0.17(21.71)$ & $3.14 \pm 0.12(10.87)$ & $2.62 \pm 0.24(4.03)$ \\
\hline HMCR & 100 & $2.66 \pm 0.12$ & $3.66 \pm 0.35(13.61)$ & $4.52 \pm 0.32 *(25.33)$ & $3.88 \pm 0.34^{*}(16.61)$ & $2.97 \pm 0.17(4.30)$ \\
\hline HMCR & 200 & $2.54 \pm 0.49$ & $3.87 \pm 0.35(17.88)$ & $4.44 \pm 0.36^{*}(25.47)$ & $4.16 \pm 0.34 *(21.66)$ & $3.14 \pm 0.24(8.04)$ \\
\hline
\end{tabular}

Each value is presented as the mean \pm SEM $(n=5) ;{ }^{*} p<0.05$ compared with the control group (Dunnett's test), ${ }^{* *} p<0.001$ compared with the control group (Dunnett's test).

\section{Formalin-induced paw licking test}

HMCR has shown a dose-dependent antinociceptive effect in both phases of Formalin test. HMCR (50, 100 and $200 \mathrm{mg} / \mathrm{kg}$ p.o.) significantly $(p<0.001)$ reduced the number of paw licking in both phases of the test when compared to control group. Morphine and diclofenac sodium, used as positive control decreased the licking significantly compared to control in both phases (Table 3).

In formalin-induced paw licking test HMCR has shown the ability to affect both the early and late phase inflammatory effects of the formalin test, which implies the involvement of not only the central mechanism but also the peripheral antinociceptive activity of the extract. The early phase, classified as neurogenic pain, is an acute response observed immediately after the administration of formalin and is due to direct action of injected formalin on nociceptors. While the late phase, classified as an inflammatory pain, is a late response resulting from the inflammatory processes generated by the release of inflammatory mediators such as histamine, serotonin, prostaglandins and bradykinin, and activation of the neurons in the dorsal horns of the spinal cord [30]. Both phases have their own characteristics that can be used as tool to assess the antinociceptive potential as well as to elucidate the mechanisms of antinociception. The early phase represents a direct irritant effect of formalin on sensory fibers, while the late phase represents response secondary to the development of inflammatory process and the release of inflammatory mediators [31]. It has been reported that drugs acting centrally (i.e. narcotics/opioids) inhibit both phases of the formalin test while those acting peripherally (i.e. NSAIDs) inhibit only the late phase, respectively [32,33]. Therefore, the results shown by HMCR suggest that the extract contains bioactive compound(s) with central and peripheral antinociceptive actions and additional antiinflammatory activity [30]. The ability of HMCR to inhibit chemically- and thermally-induced nociceptive processes tested in this study presents its potential to be used as an analgesic agent.

\section{Conclusion}

Results of the present study indicate that all tested doses of HMCR exhibited significant central and peripheral antinociceptive effect. The effect is rapid, long lasting, and statistically significant particularly at 100 and $200 \mathrm{mg} / \mathrm{kg}$ doses. Taking these findings into account, it seems quite possible that $C$. rotundus contains constituents with promising antinociceptive activity. The traditional use of the plant in the treatment of painful conditions can be affirmed by this study. However, further studies are required to isolate the bioactive compounds and elucidate the precise mechanisms responsible for the antinociceptive activity.

Table 3 Antinociceptive effect of $C$. rotundus extract, morphine and diclofenac sodium in formalin-induced paw licking test

\begin{tabular}{|c|c|c|c|c|c|}
\hline \multirow[t]{2}{*}{ Treatment } & \multirow{2}{*}{$\begin{array}{l}\text { Dose } \\
(\mathrm{mg} / \mathrm{kg})\end{array}$} & \multicolumn{4}{|c|}{ Number of licking } \\
\hline & & Early phase $(0-5 \mathrm{~min})$ & $\%$ inhibition & Late phase $(15-30 \mathrm{~min})$ & $\%$ inhibition \\
\hline Vehicle & $0.1 \mathrm{ml} / \mathrm{mice}$ & $157.00 \pm 8.21$ & - & $189.00 \pm 6.42$ & - \\
\hline Morphine sulphate & 5 & $44.20 \pm 5.44^{*}$ & 71.99 & $8.40 \pm 1.81^{*}$ & 95.56 \\
\hline Diclofenac sodium & 10 & $89.60 \pm 7.41^{*}$ & 43.22 & $35.40 \pm 2.86^{*}$ & 81.27 \\
\hline HMCR & 50 & $135.20 \pm 7.12$ & 14.32 & $90.80 \pm 8.64^{*}$ & 51.96 \\
\hline HMCR & 100 & $89.40 \pm 6.88^{*}$ & 43.35 & $51.40 \pm 9.47^{*}$ & 72.80 \\
\hline HMCR & 200 & $60.60 \pm 9.32^{*}$ & 61.60 & $23.80 \pm 5.08^{*}$ & 87.41 \\
\hline
\end{tabular}

Each value is presented as the mean $\pm \operatorname{SEM}(n=5) ;{ }^{*} p<0.001$ compared with the control group (Dunnett's test). 


\section{Competing interests}

The authors declare that they have no competing interests.

\section{Authors' contributions}

MZI conceived, designed and coordinated the study. CDS conducted the study. MZI and CDS performed the statistical analysis, interpreted the data and drafted the manuscript. Both authors read and approved the final manuscript.

\section{Acknowledgements}

We are grateful to Professor Dr. Bidyut Kanti Datta, Chairman, Department of Pharmacy, Stamford University Bangladesh, for his permission to use the facility of Pharmacology laboratory for this research work.

Received: 4 December 2013 Accepted: 25 February 2014

Published: 4 March 2014

\section{References}

1. Thanabhorn S, Jaijoy K, Thamaree S, Ingkaninan K, Panthong A: Acute and subacute toxicities of the ethanol extract from the rhizomes of Cyperus rotundus Linn. Mahidol University J Pharm Sci 2005, 32:15-22.

2. Meena AK, Yadav AK, Niranjan US, Singh B, Nagariya AK, Verma M: Review on Cyperus rotundus - A Potential Herb. Int J Pharm Clin Res 2010, 2:20-22.

3. Sivapalan SR: Medicinal uses and pharmacological activities of Cyperus rotundus Linn - A Review. Int J Sci Res Pub 2013, 3:1-8.

4. Singh N, Pandey BR, Verma P, Bhalla M, Gilca M: Phytopharmacotherapeutics of Cyperus rotundus Linn. (Motha): an overview. Indian J Nat Prod Res 2012, 3:467-476.

5. Duarte MC, Figueira GM, Sartoratto A, Rehder VL, Delarmelina C: Anti-Candida activity of Brazilian medicinal plants. J Ethnopharmacol 2005, 97:305-311.

6. Sundaram MS, Sivakumar T, Balamurugan G: Anti-inflammatory effect of Cyperus rotundus Linn. leaves on acute and subacute inflammation in experimental rat models. Biomed 2008, 28:302-304.

7. Raut NA, Gaikwad NJ: Antidiabetic activity of hydro-ethanolic extract of Cyperus rotundus in alloxan induced diabetes in rats. Fitoterapia 2006, 77:585-588.

8. Uddin SJ, Modal K, Shilpi JA, Rahman MT: Antidiarrhoeal activity of Cyperus rotundus. Fitoterapia 2006, 77:134-136.

9. Daswani PG, Brijesh S, Tetali P, Birdi TJ: Studies on the activity of Cyperus rotundus Linn. tubers against infectious diarrhea. Indian J Pharmacol 2011, 43:340-344.

10. Zhu M, Luk HH, Fung HS, Luk CT: Cytoprotective effects of Cyperus rotundus against ethanol induced gastric ulceration in rats. Phytother Res 1997, 11:392-394.

11. Kilani S, Ben Ammar R, Bouhlel I, Abdelwahed A, Hayder N, Mahmoud A, Ghedira K, Chekir-Ghedira L: Investigation of extracts from (Tunisian) Cyperus rotundus as antimutagens and radical scavengers. Environ Toxicol Pharmacol 2005, 20:478-484.

12. Pal DK, Dutta S: Evaluation of the antioxidant activity of the roots and rhizomes of Cyperus rotundus L. Indian J Pharm Sci 2006, 68:256-258.

13. Kilani S, Ben Sghaier M, Limem I, Bouhlel I, Boubaker J, Bhouri W, Skandrani I, Neffatti A, Ben Ammar R, Dijoux-Franca MG, Ghedira K, Chekir-Ghedira L: In vitro evaluation of antibacterial, antioxidant, cytotoxic and apoptotic activities of the tubers infusion and extracts of Cyperus rotundus. Bioresour Technol 2008, 99:9004-9008.

14. Kilani S, Ledauphin J, Bouhlel I, Ben Sghaier M, Boubaker J, Skandrani I, Mosrati R, Ghedira K, Barillier D, Chekir-Ghedira L: Comparative study of Cyperus rotundus essential oil by a modified GC/MS analysis method. Evaluation of its antioxidant, cytotoxic, and apoptotic effects. Chem Biodivers 2008, 5:729-742.

15. Soumaya K-J, Dhekra M, Fadwa C, Zied G, llef L, Kamel G, Leila C-G: Pharmacological, antioxidant, genotoxic studies and modulation of rat splenocyte functions by Cyperus rotundus extracts. BMC Compl Alt Med 2013, 13:28.

16. Shivakumar SI, Suresh HM, Hallikeri CS, Hatapakki BC, Handiganur JS, Sankh K, Shivakumar B: Anticonvulsant effect of Cyperus rotundus Linn rhizomes in rats. J Nat Rem 2009, 9:192-196.

17. Puratchikody A, Devi CN, Nagalakshmi G: Wound healing activity of Cyperus rotundus Linn. Indian J Pharm Sci 2006, 68:97-101.
18. Walker CIB, Trevisan G, Rossato MF, Franciscato C, Pereira ME, Ferreira J, Manfron MP: Antinociceptive activity of Mirabilis jalapa in mice. J Ethnopharmacol 2008, 120:169-175.

19. Eddy NB, Leimbach D: Synthetic analgesics: II. Dithienylbutenyl and Dithienylbutylamines. J Pharmacol Exp Ther 1953, 107:385-393.

20. Toma W, Graciosa JS, Hiruma-Lima CA, Andrade FDP, Vilegas W, Souza Brito ARM: Evaluation of the analgesic and antiedematogenic activities of Quassia amara bark extract. J Ethnopharmacol 2003, 85:19-23.

21. Lapa FR, Gadotti VM, Missau FC, Pizzolatti MG, Marques MC, Dafré AL, Farina M, Rodrigues AL, Santos AR: Antinociceptive properties of the hydroalcoholic extract and the flavonoid rutin obtained from Polygala paniculata L. in mice. Basic Clin Pharmacol Toxicol 2009, 104:306-315.

22. Santos AR, Calixto JB: Further evidence for the involvement of tachykinin receptor subtypes in formalin and capsaicin models of pain in mice. Neuropeptides 1997, 31:381-389.

23. Santos AR, Miguel OG, Yunes RA, Calixto JB: Antinociceptive properties of the new alkaloid, cis-8, 10-di- $N$-propyllobelidiol hydrochloride dihydrate isolated from Siphocampylus verticillatus: Evidence for the mechanism of action. J Pharmacol Exp Ther 1999, 289:417-426.

24. Parada CA, Tambeli CH, Cunha FQ, Ferreira SH: The major role of peripheral release of histamine and 5-hydroxytryptamine in formalininduced nociception. Neurosci 2001, 102:937-944.

25. Pini LA, Vitale G, Ottani A, Sandrini M: Naloxone-reversible antinociception by paracetamol in the rat. J Pharmacol Exp Ther 1997, 280:934-940.

26. Hosseinzadeh $H$, Younesi HM: Antinociceptive and anti-inflammatory effects of Crocus sativus L. stigma and petal extracts in mice. BMC Pharmacol 2002, 2:7.

27. Katzung BG: Basic and Clinical Pharmacology. 6th edition. Appleton \& Lange: Norwalk; 1995

28. Srinivasan K, Muruganandan S, Lal J, Chandra S, Tandan SK, Raviprakash V, Kumar D: Antinociceptive and antipyretic activities of Pongamia pinnata leaves. Phytother Res 2003, 17:259-264.

29. Arslan R, Bektas N: Antinociceptive effect of methanol extract of Capparis ovata in mice. Pharm Biol 2010, 48:1185-1190.

30. Sani MHM, Zakaria ZA, Balan T, Teh LK, Salleh MZ: Antinociceptive activity of methanol extract of Muntingia calabura leaves and the mechanisms of action involved. Evidence-Based Compl Alt Med 2012. Article ID 890361, doi:10.1155/2012/890361.

31. Hunskaar S, Hole K: The formalin test in mice: Dissociation between inflammatory and non-inflammatory pain. Pain 1987, 1987(30):103-114.

32. Shibata M, Ohkubo T, Takahashi H, Inoki R: Modified formalin test: Characteristic biphasic pain response. Pain 1989, 38:347-352.

33. Santos AR, Filho VC, Niero R, Viana AM, Moreno FN, Campos MM, Yunes RA, Calixto JB: Analgesic effects of callus culture extracts from selected species of Phyllanthus in mice. J Pharm Pharmacol 1994, 1994(46):755-759.

doi:10.1186/1472-6882-14-83

Cite this article as: Imam and Sumi: Evaluation of antinociceptive activity of hydromethanol extract of Cyperus rotundus in mice. BMC Complementary and Alternative Medicine 2014 14:83.

\section{Submit your next manuscript to BioMed Central and take full advantage of:}

- Convenient online submission

- Thorough peer review

- No space constraints or color figure charges

- Immediate publication on acceptance

- Inclusion in PubMed, CAS, Scopus and Google Scholar

- Research which is freely available for redistribution 